\title{
Construction of Full-length Infectious cDNA Clones of Apple chlorotic leaf spot virus and Their Agroinoculation to Woody Plants by a Novel Method of Vacuum Infiltration
}

Lei Zhang, Julius Kühn-Institut, Federal Research Centre for Cultivated Plants, Institute for Plant Protection in Fruit Crops and Viticulture, D69221 Dossenheim, and Ruprecht-Karls-Universität Heidelberg, Centre for Organismal Studies, 69120 Heidelberg, Germany; and Wilhelm Jelkmann, ${ }^{\dagger}$ Julius Kühn-Institut, Federal Research Centre for Cultivated Plants, Institute for Plant Protection in Fruit Crops and Viticulture, D-69221 Dossenheim, Germany

\begin{abstract}
Construction and agroinoculation of full-length infectious cDNA clones of plant RNA viruses have been used in plant virology to prove Koch's postulates and for development of viruses as vectors for expressing foreign genes in plants. Four full-length cDNA clones (pIF3-12, pIF3-14, pIF3-15, and pIF3-19) of Apple chlorotic leaf spot virus (ACLSV) isolate 38/85 were produced. Two of the four full-length cDNA clones (pIF3-15 and pIF3-19) proved to be infectious on Nicotiana occidentalis 37B test plants by agroinoculation and were then mechanically transmissible to healthy $N$. occidentalis 37B. The genomic cDNAs of ACLSV pIF3-15 and pIF3-19 shared nucleotide identity of $77.5 \%$, demonstrating mixed

infections of multiple strains of ACLSV in the source tree of isolate 38/85. The two full-length cDNA clones were agroinoculated to apple seedlings by a newly developed vacuum infiltration method. The success rate of agroinoculation was greater than $78 \%$, defined as the number of PCR positive seedlings to the number of apple seedlings that survived. ACLSV was transmissible from agroinoculated seedlings by cleft grafting. The results of this study will be useful for construction of infectious cDNA clones of plant viruses from full-length PCR fragments and agroinoculating woody host plants using the vacuum infiltration method outlined here.
\end{abstract}

Apple chlorotic leaf spot virus (ACLSV) is one of the most widely distributed viruses of fruit trees (Sutton et al. 2014). It is transmitted by grafting, sap inoculation, and vegetative propagation (Németh 1986). It is believed that ACLSV is only transmitted in the field by vegetative propagation of rootstocks and pome and stone fruit cultivars (Yaegashi et al. 2011). There is no evidence of vector, seed, or pollen transmission in any of its hosts (Yoshikawa 2001). ACLSV infects many pome and stone fruit species (Myrta et al. 2011; Yaegashi et al. 2011) and has been implicated in several diseases, such as apple top working, apple russet ring, and pear ring pattern mosaic (Cropley et al. 1963; Desvignes and Boyé 1988; Yanase 1974). Symptom severity of ACLSV infection can vary by virus isolates. For example, severe isolates elicit a "pseudopox" disease of apricots (Desvignes and Boyé 1988), and some isolates induce "false plum pox" symptoms on some plum cultivars (Jelkmann and Kunze 1994; Lebas et al. 2003).

ACLSV is the type species of the genus Trichovirus in the family Betaflexiviridae. The genome of ACLSV is composed of a singlestranded plus-sense RNA molecule of $\sim 7,500$ nucleotides, excluding poly-A tail, and is encapsulated by coat protein subunits of a single type (Yoshikawa and Takahashi 1988).

Infectious cDNA clones are powerful tools that can be used to prove Koch's postulates, investigate virus replication and host interactions, and develop expression vectors (Boyer and Haenni 1994; Nagyová and Subr 2007). The first infectious clone of a plant RNA virus, Brome mosaic virus, was obtained in 1984 (Ahlquist et al. 1984). Since then, infectious clones to a wide range of virus species belonging to several virus families such as Alphaflexiviridae, Betaflexiviridae, Bromoviridae, Closteroviridae, Luteoviridae, Potyviridae, and Tymoviridae have been produced (Dawson et al.

\section{${ }^{\dagger}$ Corresponding author. E-mail: Wilhelm.Jelkmann@julius-kuehn.de}

*The $\boldsymbol{e}$-Xtra logo stands for "electronic extra" and indicates that one supplementary figure is published online.

Accepted for publication 5 July 2017.

() 2017 The American Phytopathological Society
1986; Desbiez et al. 2012; Domier et al. 1989; Edwards et al. 2015; Hemenway et al. 1990; Tuo et al. 2015).

The construction of infectious cDNA clones is generally laborious, time consuming, and unpredictable with additional challenges when working with viruses from woody plants. Among the difficulties relevant for the construction of ACLSV infectious clones are low virus titers in woody hosts, high variability of virus strains, the length of the viral genomic cDNA $(\sim 7.5 \mathrm{~kb}$, making one-step cloning poorly efficient), and the presence of inhibitory substances such as polyphenolic compounds or polysaccharides in fruit trees, resulting in low concentration of viral products in PCR amplification (MacKenzie et al. 1997; Meng et al. 2013). The first infectious clone of ACLSV (isolate P-205) was constructed in 1999 (Satoh et al. 1999). Infectivity of this clone was demonstrated by particle bombardment and limited to Chenopodium quinoa. To overcome the difficulties in making infectious cDNA clones from woody hosts, a technique of In-Fusion cloning (Tuo et al. 2015) was applied to construction of ACLSV cDNA clones.

It is difficult to transmit viruses to woody hosts such as grapevine and apple by conventional mechanical inoculation methods (Yamagishi et al. 2010). Similarly, it is generally difficult to inoculate these hosts with infectious cDNA clones, including techniques such as agroinoculation and particle bombardment. For example, Apple latent spherical virus was transmitted to apple trees with poor efficiency (Ito et al. 1992; Li et al. 2004). Grapevine virus B was transmitted by sap inoculation to hosts with great difficulty (Boscia et al. 1993; Conti et al. 1980). Citrus tristeza virus was transmitted effectively to Etrog citron by cutting or slashing the plant stem with a contaminated blade (Garnsey et al. 1977). However, infectious transcripts of ACLSV were not mechanically transmissible to woody hosts (peach or apple) using stem slashing (Yamagishi et al. 2010; Youssef et al. 2011a).

Various inoculation methods have been developed, such as biolistic inoculation, syringe infiltration, and agrodrench, all with varying levels of success. For example, the total RNAs extracted from Apple latent spherical virus-infected or ACLSV-infected C. quinoa leaves establish infection in high efficiency on apple seedlings by particle bombardment (Yamagishi et al. 2010). A full-length cDNA clone of Citrus leaf blotch virus was inoculated to Etrog citron plants with high efficiency by syringe infiltration (Vives et al. 2008). Full-length cDNA clones of Grapevine rupestris stem pitting-associated virus and Grapevine virus $A$ were introduced to Vitis vinifera plantlets 
by modified agrodrench (Meng et al. 2013; Muruganantham et al. 2009).

Thus, there is a need to further establish simple and effective inoculation methods especially for woody host plants. In this study, we constructed infectious cDNA clones from full-length PCR fragments and established a simple and highly efficient agroinoculation method to apple seedlings by vacuum infiltration. The method was employed to allow simple and cost-effective inoculation of single strains of ACLSV to apple, which will enhance our understanding of the impact of defined genomes of this highly variable virus.

\section{Materials and Methods}

Virus source. The ACLSV isolate 38/85 used in this work was originally identified in an infected apple tree in Germany in the 1980 s. It was tested by woody indexing at the former Biologische Bundesanstalt für Land- und Forstwirtschaft (BBA), Dossenheim. It was propagated and maintained on a rootstock of Malus communis Bittenfelder seedling in the virus source collection center of the Julius Kühn-Institut (JKI), Dossenheim. The infected tree showed symptoms of decline.

Construction of full-length cDNA clones. The plasmid of the binary vector pV297, kindly donated by Edgar Maiss, Leibniz University, Hannover, Germany, was linearized by PCR. pV297 is modified from pCB301 (Xiang et al. 1999) and possesses a CaMV 35S promoter and the hepatitis delta viral ribozyme sequence followed by a CaMV 35S polyadenylation signal. The linear pV297 were prepared by PCR using the primers 297exACLSV-IF-F: TAAATATT TTACTACGGGTCGGCATGGCATCTC / 297exACLSV-IF-R: ACTGTATCAGTATCACCTCTCCAAATGAAATGAAC.Theprimers anneal to the hepatitis delta viral ribozyme region and the CaMV 35S promoter region of $\mathrm{pV} 297$, respectively. The underlined 15 nucleotides were homologous to $3^{\prime}$ and $5^{\prime}$ termini of the genomic cDNA of ACLSV isolate 38/85, respectively. The PCR reaction mix $(50 \mu \mathrm{l})$ consisted of $10 \mu \mathrm{l}$ of $5 \times$ Hifi Buffer (offered with the polymerase), $6.5 \mu \mathrm{l}$ of $2 \mathrm{mM}$ dNTPs, $2 \mu \mathrm{l}$ of each primer $(10 \mu \mathrm{M}), 1 \mu \mathrm{l}$ of Precisor High-Fidelity DNA Polymerase (BioCat GmbH, Germany), and $0.1 \mathrm{ng}$ of the plasmid pV297 and $\mathrm{H}_{2} \mathrm{O}$ (HPLC grade, PanReac AppliChem). The thermal parameters were $98^{\circ} \mathrm{C} 2 \mathrm{~min}, 35$ cycles of $98^{\circ} \mathrm{C} 30 \mathrm{~s}, 55^{\circ} \mathrm{C} 30 \mathrm{~s}$ and $72^{\circ} \mathrm{C} 2.5 \mathrm{~min}$, and $72^{\circ} \mathrm{C} 5 \mathrm{~min}$. After amplification the sample was digested with FastDigest DpnI (Thermo Fisher, Waltham, MA) to digest DNA with methylation, which removes the plasmid grown in bacteria but not the amplified plasmid with the ACLSV ends.

The full-length genomic cDNAs of ACLSV isolate 38/85 were prepared by RT-PCR. Total RNAs were extracted from 100-mg fresh leaf blades of the infected apple tree using RNeasy Plant Mini Kit (Qiagen, Hilden, Germany). The cDNAs were generated using RevertAid Premium Reverse transcription (Thermal Scientific) with Oligo(dT) 18 following the manufacturer's instructions. The full-length fragments of the genomic cDNAs were amplified using primers ACLSV-F: TGATACTGATACAGTGTACACTCAC / ACLSV-R: GTAGTAA AATATTTAAAAGTCTACAGG. The PCR reaction mix $(50 \mu \mathrm{l})$ consisted of $10 \mu \mathrm{l}$ of $5 \times$ GC Buffer (offered with the polymerase), $6.5 \mu \mathrm{l}$ of $2 \mathrm{mM}$ dNTPs, $2 \mu \mathrm{l}$ of each primer $(10 \mu \mathrm{M}), 1 \mu \mathrm{l}$ of the Precisor High-Fidelity DNA Polymerase (BioCat GmbH, Germany), $8 \mu \mathrm{l}$ of the cDNA template and $\mathrm{H}_{2} \mathrm{O}$ (HPLC grade). The thermal parameters were $98^{\circ} \mathrm{C} 2 \mathrm{~min}, 35$ cycles of $98^{\circ} \mathrm{C} 30 \mathrm{~s}, 51^{\circ} \mathrm{C} 30 \mathrm{~s}$ and $72^{\circ} \mathrm{C} 4 \mathrm{~min}$, and $72^{\circ} \mathrm{C} 8 \mathrm{~min}$.

The PCR amplified pV297 with ACLSV ends and the full-length genomic ACLSV cDNAs were purified using Quick Gel Extration kit (QIAX) (Qiagen). The concentration of the purified fragments was measured using Invitrogen Qubit 2.0 Fluorometer (Thermo Fisher). The gel purified fragments were fused using In-Fusion HD cloning kit (Clontech, Mountain View, CA). The reaction mix $(17 \mu \mathrm{l})$ consisted of $10 \mu \mathrm{l}(55 \mathrm{ng})$ of the full-length genomic cDNAs of ACLSV isolate 38/85, $3.6 \mu \mathrm{l}(67.5 \mathrm{ng})$ of the linear pV297 and $3.4 \mu \mathrm{l}$ of $5 \times$ In-Fusion HD Enzyme Premix. The reaction mix was incubated at $50^{\circ} \mathrm{C}$ for $1 \mathrm{~h}$. There is a 15 base $5^{\prime}$ to $3^{\prime}$ digestion in the In-Fusion reaction that results in 15 base overlapping ends on the pV297 with ACLSV ends and the full-length ACLSV cDNAs.
After reaction one half of the mix was directly used in transformation of NEB $10 \beta$ competent E. coli (New England Biolabs, Ipswich, MA).

Positive colonies were selected by kanamycin resistance (30 $\mathrm{mg} /$ liter) and multiple colony PCRs to identify candidate ACLSV full-length cDNA clones. Two primer pairs of ACLSVdet-01-F: AAC GCTCTTTTCTCTTAGGT / ACLSVdet-02-R: GAGGCGTTAC GTCAATCTGT (annealing at $52^{\circ} \mathrm{C}$ ) and ACLSVdet-03-F: GGTA TTTAATTGGAGTGTTT / ACLSVdet-04-R: TACAAATACAAA TACATACTAAGG (annealing at $48^{\circ} \mathrm{C}$ ) were designed, which encompassed the cloning sites of pV297 and the genomic cDNAs of ACLSV isolate 38/85. The primer pair of ACLSV-6860F: TTCATGGAAAGACAGGGGCAA / ACLSV-7507R: AAGTCTA CAGGCTATTTATTATAAGTCTAA (Menzel et al. 2002) was also used for the selection of positive colonies. The plasmids of the positive colonies were extracted using QIAprep Spin Miniprep kit (Qiagen). The plasmids were delivered into competent $A$. tumefaciens strain ATHV by electroporation.

The infectious and one noninfectious full-length cDNA clones were sequenced step-by-step (Eurofins Genomics, Ebersberg, Germany). The sequences were analyzed using the online tool of NCBI BLASTn, MEGA5 and Lasergene version 7.1.0 (DNASTAR).

Agroinoculation of herbaceous plants. The A. tumefaciens containing the full-length cDNA clones was incubated overnight at $28^{\circ} \mathrm{C}$ in YEB medium (Vervliet et al. 1975) containing $2 \mathrm{M} \mathrm{MgSO}_{4}, 30$ $\mathrm{mg} / \mathrm{liter}$ kanamycin and $25 \mathrm{mg} / \mathrm{liter}$ rifampicin. The A. tumefaciens containing pV297 was used as a negative control. The harvested agrobacteria were resuspended in $10 \mathrm{mM} \mathrm{MgSO} 4$ buffer to a final $\mathrm{OD}_{600}$ of approximately 1.20 . Four full-length cDNA clones were each mechanically agroinoculated onto 10 plants of Nicotiana occidentalis $37 \mathrm{~B}$ at the four-leaf stage. The inocula were gently rubbed onto the upper surface of two or three leaves of test plants. Before inoculation the leaves were dusted with Carborundum (600 mesh). Plants were observed daily for symptom development for three weeks. The infection of ACLSV was confirmed by RT-PCR and immunoelectron microscopy (IEM) in leaves that developed after inoculation as described below.

Vacuum infiltration of apple seedlings. One- to three-month-old seedlings grown from seeds of virus-tested $M$. domestica 'Golden Delicious' were used as test plants. The seedlings were germinated and maintained in the dark at $4{ }^{\circ} \mathrm{C}$ (refrigerator) until use. Before vacuum infiltration, the brown seed coats on cotyledons were removed, and the seedlings were taken to room temperature $\left(\sim 20^{\circ} \mathrm{C}\right)$ for around $20 \mathrm{~h}$ under natural light until cotyledons turned light green. Wounded or unwounded seedlings were used in the experiments. For wounding, the two cotyledons of the seedlings were stuck by a sterilized needle to introduce 4 to 6 pin holes (Fig. 1). The entire wounded or unwounded seedlings were immersed in sterilized Milli-Q water containing $1 \%(\mathrm{v} / \mathrm{v})$ Tween 80 for $10 \mathrm{~min}$, and rinsed two times with sterilized Milli-Q water. Prepared seedlings were then immediately immersed in the inocula for vacuum infiltration.

The inocula of transformed A. tumefaciens were prepared as described above for inoculation of herbaceous hosts with the additional of $0.2 \%(\mathrm{v} / \mathrm{v})$ Tween 20 . The A. tumefaciens containing plasmid pV297 was used as the negative control. The vacuum was generated in a closed desiccator by Büchi V-500 vacuum pump with Büchi vacuum controller B-721 (Sigma-Aldrich GmbH, Munich, Germany). Three treatments of vacuum infiltration were evaluated: $50 \mathrm{hPa}$ (38 mm Hg) for $5 \mathrm{~min}$ (treatment 1); $500 \mathrm{hPa}(375 \mathrm{~mm} \mathrm{Hg}$ ) for 2, 5 , and $10 \mathrm{~min}$ (treatment 2); and $500 \mathrm{hPa}$ for 5 min (treatment 3 ). Wounded and unwounded seedlings were used in treatment 1 , while only wounded seedlings were used in treatment 2 and 3 .

After vacuum infiltration, seedlings were immediately planted in sterilized soil and grown under glasshouse conditions at 60 to $65 \%$ humidity, with $16-\mathrm{h}$ daylight, and at 20 to $25^{\circ} \mathrm{C}$. Plants were tested for ACLSV by RT-PCR and examined by IEM 56 days and 70 days after inoculation, respectively.

Sap inoculation and grafting. For each infectious cDNA clone, five $N$. occidentalis 37B plants were mechanically inoculated using leaf sap from the $N$. occidentalis $37 \mathrm{~B}$ plants that had been 
agroinoculated. The leaf sap inoculum was prepared by homogenizing the newly developed symptomatic leaf blades in inoculation buffer [ $(0.07 \mathrm{M}$ phosphate buffer, $0.01 \mathrm{M}$ Sodium diethyldithiocarbamate trihydrate and $0.02 \mathrm{M}$ Sodium thioglycolate, $\mathrm{pH} 7.0)(1 \mathrm{~g}$ fresh leaf blades: $100 \mathrm{ml}$ inoculation buffer)]. Sap extracted from healthy plants was used as the negative control. Two or three Carborundum dusted leaves were inoculated on each test plant when it was at the four-leaf stage.

Healthy apple seedlings were inoculated by cleft grafting. Healthy 6-month-old seedlings of $M$. domestica 'Golden Delicious' were used as root stocks. The top buds of the agroinoculated apple seedlings were used as scions. Four rootstocks were grafted for each infectious cDNA clone. All mechanically inoculated or grafted test plants were kept under glasshouse conditions as described above. The infection of ACLSV in N. occidentalis 37B and M. domestica 'Golden Delicious' was determined by RT-PCR and IEM 10 days and 90 days after inoculation, respectively.

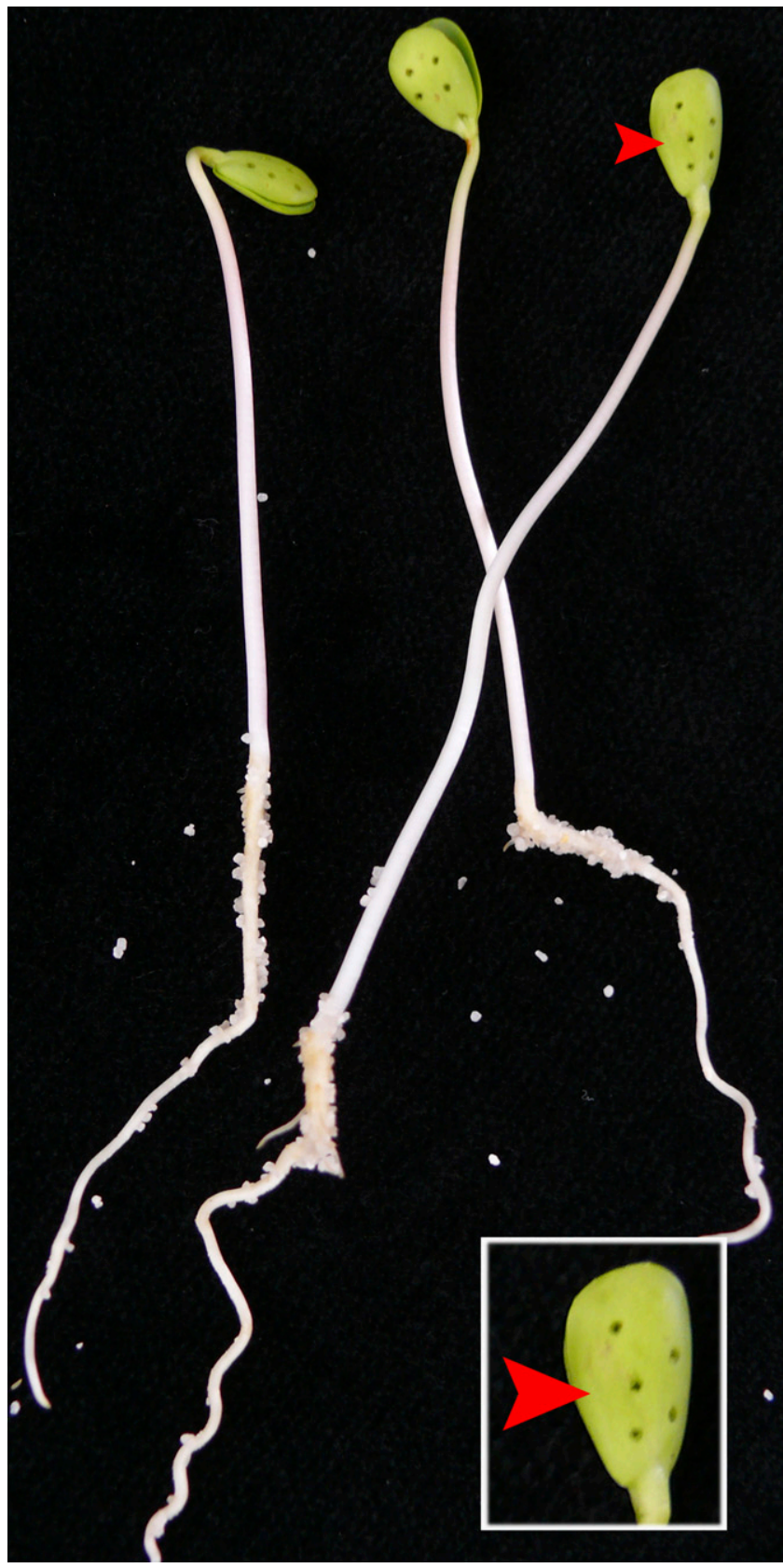

Fig. 1. Apple seedlings with wounded cotyledons (inset) used in vacuum infiltration. The red arrow indicates a wounded cotyledon.
RT-PCR and immunoelectron microscopy (IEM). ACLSV was detected in inoculated test plants by RT-PCR. Total nucleic acids of the test plants were extracted using a Silica method (Rott and Jelkmann 2001). The cDNAs were produced using RevertAid Reverse transcription with Oligo $(\mathrm{dT})_{18}$ following the manufacturer's instruction (Thermo Scientific). The fragments of ACLSV were amplified using FastGene Taq DNA polymerase (Nippon genetics Europe GmbH) with primers ACLSV-6860F / -7507R. The PCR reaction mix $(12.5 \mu \mathrm{l})$ consisted of $1.25 \mu \mathrm{l}$ of $10 \times$ Buffer A, $0.25 \mu \mathrm{l}$ of $10 \mathrm{mM}$ dNTPs, $0.5 \mu$ l of each primer $(10 \mu \mathrm{M}), 0.05 \mu \mathrm{l}$ of the DNA polymerase, and $1.25 \mu \mathrm{l}$ cDNA reaction mix and $\mathrm{H}_{2} \mathrm{O}$ (HPLC grade). The thermal parameters were $95^{\circ} \mathrm{C} 2 \mathrm{~min}, 35$ cycles of $95^{\circ} \mathrm{C} 30 \mathrm{~s}, 55^{\circ} \mathrm{C}$ $30 \mathrm{~s}$, and $72^{\circ} \mathrm{C} 45 \mathrm{~s}$.

Viral particles of ACLSV were visualized in the test plants by IEM as described previously (Jelkmann et al. 1990). The polyclonal antiserum used was ACLSV-AS1236 (JKI, Institute for Epidemiology and Pathogen Diagnostics).

\section{Results}

Full-length ACLSV cDNA clone construction. In total, four fulllength ACLSV isolate 38/85 cDNA clones were obtained using InFusion cloning. The gel purified fragments of the linear vector of pV297 (ca. $4.3 \mathrm{~kb})$ and the full-length genomic cDNAs $(\sim 7.5 \mathrm{~kb})$ (Supplementary Fig. S1), which have the overlapping fragments of $15 \mathrm{bp}$ at the terminal ends, were fused using In-Fusion cloning. After transformation of NEB $10 \beta$ competent E. coli, 36 single colonies grew on LB plates containing kanamycin $(30 \mathrm{mg} / \mathrm{liter})$ and these were further evaluated by PCR. Of the 36 colonies, only four were positive based on PCR amplicon sizes of ca. 600, 340, and $680 \mathrm{bp}$ using primer pairs ACLSVdet-01-F/-02-R, ACLSVdet-03-F/-04-R, and ACLSV-6860F/-7507R, respectively. The four plasmids of the full-length cDNA clones were marked pIF3-12, pIF3-14, pIF3-15, and pIF3-19.

Infectivity of ACLSV full-length cDNA clones. Each of the four full-length cDNA clones was mechanically agroinoculated onto 10 healthy $N$. occidentalis 37B. Two of the four full-length cDNA clones, pIF3-15 and pIF3-19, were infectious on $N$. occidentalis 37B (Fig. 2A and B), based on symptoms, PCR, and IEM tests. Symptom development was observed over 21 days. Full-length cDNA clones pIF3-15 and pIF3-19 caused typical ACLSV symptoms and systemic infections. All infected plants initially developed yellow spots on noninoculated leaves seven to nine days after inoculation. Over time the symptoms of chlorosis, leaf crinkle, and some necrotic spots were observed on upper leaves (Fig. 2A and B). No symptoms developed on the inoculated leaves. Healthy control plants agroinoculated with plasmid pV297 remained symptomless (Fig. 2C). All symptomatic plants were PCR positive using primers ACLSV-6860F/-7507R. For each cDNA clone of pIF3-15 and pIF3-19, three tested symptomatic $N$. occidentalis 37B plants showed virus particles in IEM (Fig. 3A and B). The virus can be transmitted from the agroinoculated pIF3-15 and pIF3-19 N. occidentalis $37 \mathrm{~B}$ to healthy plants. The infection of ACLSV was confirmed by RT-PCR and IEM.

Heterogeneity of ACLSV infectious cDNA clones from a single source. Although ACLSV full-length infectious cDNA clones pIF3-15 and pIF3-19 were obtained from the same source, their

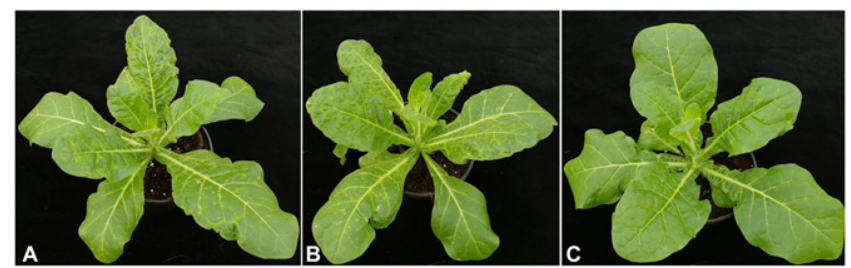

Fig. 2. Agroinoculated $N$. occidentalis $37 B$ with infectious cDNA clones of ACLSV isolate $38 / 85$. The pictures were taken 15 days p-inoculation: $\mathbf{A}$, agroinoculation of pIF3-15; B, agroinoculation of pIF3-19; C, the negative control of agroinoculation of pV297. 
genomes shared only $77.5 \%$ nucleotide sequence identity. The sequences were deposited in NCBI database under accession numbers KX579122 and KX579123, respectively. The corresponding ACLSV variants in agroinfected plants were designated ACLSV 38/85A and 38/85B. The genome of ACLSV 38/85A consisted of 7,561 nucleotides and 38/85B was 7,544 nucleotides in length. The $\mathrm{CP}$ amino acids determine the groups and pathogenicity of ACLSV (Chen et al. 2014; Yaegashi et al. 2007). The cluster of the five conserved amino acids was $\mathrm{Ser}^{40} \mathrm{Leu}^{59}-\mathrm{Tyr}^{75}-\mathrm{Thr}^{130}{ }^{13 e u^{184}}$ for strain 38/85A and $\mathrm{Ala}^{40}$ $\mathrm{Val}^{59}-\mathrm{Phe}^{75}-\mathrm{Ser}^{130}-\mathrm{Met}^{184}$ for strain $38 / 85 \mathrm{~B}$.

Of the two noninfectious cDNA clones, pIF3-14 was sequenced. In comparison with the infectious cDNA clone pIF3-19, pIF3-14 has only one additional $\mathrm{T}$ at position $\mathrm{nt} 1,702$, resulting in a frameshift of ORF1. For the second noninfectious cDNA clone pIF3-12 777 nt (complete $\mathrm{CP}$ gene and $3^{\prime}$ untranslated region) at the $3^{\prime}$ and $523 \mathrm{nt}$ ( $5^{\prime}$ untranslated region and partial RNA-dependent RNA polymerase gene) at the $5^{\prime}$ terminus were analyzed. The identity at the $3^{\prime}$ end to cDNA clones pIF3-15 and pIF3-19 was $87.3 \%$ and $85.0 \%$, respectively, and $85.8 \%$ and $87.0 \%$ at the $5^{\prime}$ end.

Phylogenetic analysis using Lasergene MegAlign indicated that ACLSV isolate 38/85A shared identities of 67.2 to $78.5 \%$ to the 18 published sequences of complete ACLSV genomes, while ACLSV isolate 38/85B showed identities of 68.1 to $79.4 \%$ (data not shown). Accession numbers of sequences included in alignments were AB326223, AB326224, AB326225, D14996, EU223295, HE980332, JN634760, JN634761, KC935954, KC935955, KC935956, KJ522693, KM207212, KU870524, KU870525, M58152, NC_001409, and X99752.

Inoculation of ACLSV full-length cDNA clones by vacuum infiltration to apple seedlings. The infectious full-length cDNA clones of pIF3-15 and pIF3-19 were agroinoculated to apple seedlings by vacuum infiltration. In treatment 1 , using $50 \mathrm{hPa}$ for $5 \mathrm{~min}, 23$ wounded and 35 unwounded seedlings were agroinoculated with pIF3-19, and 10 wounded and 9 unwounded seedlings were agroinoculated with pV297 as negative controls. Two weeks after vacuum infiltration, unwounded seedlings grew well while nearly half of the 23 wounded seedlings wilted and declined. Seven weeks after the treatment, only 5 out of the 23 wounded and 18 out of the 35 unwounded seedlings survived. Four of the 5 wounded and 2 of the 18 unwounded surviving seedlings tested positive for ACLSV infection by RT-PCR using primers ACLSV-6860F/-7507R, (Fig. 4A). These results were confirmed by IEM.

In treatment 2, an optimized vacuum infiltration time was evaluated. The inoculum was pIF3-19 using duration times of 2, 5, and $10 \mathrm{~min}$, respectively. The results are summarized in Figure 4B. The efficiency of agroinoculation at 5 and $10 \mathrm{~min}$ was comparable. For further experiments, 5 min vacuum infiltration time was used because the survival rate of seedlings in the healthy control experiment with pV297 declined over vacuum exposure time.

In treatment 3 , using $500 \mathrm{hPa}$ for $5 \mathrm{~min}, 10$ to 15 wounded seedlings were agroinoculated with pIF3-15, pIF3-19 and pV297, respectively. After the treatment the seedlings grew well the first two weeks and the overall survival rate was greater than $70 \%$ seven weeks after vacuum infiltration. Of the surviving apple seedlings inoculated with pIF3-15 and pIF3-19 greater than 78\% tested positive for ACLSV based on RT-PCR detection (Fig. 4C). For each of the cDNA clones, pIF3-15 and pIF3-19, one RT-PCR negative and three RT-PCR positive seedlings were also tested by IEM for confirmation. The IEM results were consistent with the RT-PCR results. By cleft grafting, the virus was transmitted from pIF3-15 and pIF3-19 infected scions to healthy $M$. domestica 'Golden Delicious'. The infection of ACLSV in all grafted seedlings was confirmed by RT-PCR and IEM.

\section{Discussion}

In the present work, four full-length cDNA clones (pIF3-12, pIF314, pIF3-15, and pIF3-19) of ACLSV isolate $38 / 85$ were obtained using In-Fusion cloning. Two very distantly related (77.5\% nt identity) strains of ACLSV were represented in these cDNA clones, pIF3-15 and pIF3-19, that were infectious on $N$. occidentalis 37B. This indicated the existence of different ACLSV strains in the apple source tree. Using a unique vacuum infiltration technique, pIF3-15 and pIF3-19 were successfully agroinoculated to apple seedlings and resulted in systemic infection.

Compared with cloning systems that depend on several cloned or PCR amplified cDNA fragments and their ligation, In-Fusion cloning has an advantage of simplicity and is ligation independent. In previous work of construction of infectious full-length cDNA clones of ACLSV P-205, restriction digestion and a ligation-based method (Satoh et al. 1999), or an in vivo yeast system (Youssef et al. 2011a), were used. The restriction digestion and ligation-based method requires unique and specific sites in both the insert and the vector and the ligation steps are usually inefficient (Stevenson et al. 2013). The in vivo yeast system has the advantage of avoiding ligation; however, the strategy requires a ternary yeast- $E$. coli-A. tumefaciens vector. Multiple transformation steps in $E$. coli, yeast, and A. tumefaciens increase the risk of mutations of the cDNA clones. When compared with the two methods described previously for ACLSV full-length clone construction, In-Fusion cloning is simpler as specific restriction sites in the insert and the vector are not required, and inefficient ligation steps and a ternary vector are avoided. The overlapping 15 nucleotides between vector and viral insert can be exactly cloned by In-Fusion. This was confirmed by sequencing the cloning sites of the four full-length clones pIF3-12, pIF3-14, pIF3-15, and pIF3-19. Extra nonviral nucleotides might significantly reduce virus infectivity (Hans et al. 1992; Janda et al. 1987). The lack of infectivity for the ACLSV clones pIF3-12 and pIF3-14 was not due to problems at the cloning sites. For clone pIF3-14, a frameshift in the polymerase region was determined and assumed to be the reason for lack of infectivity. Clone pIF3-12 showed considerable variation in the $3^{\prime}$ and $5^{\prime}$ terminal nucleotides in comparison with the two infectious clones. Either this variation or possible unexpected mutation(s) during PCR, or during E. coli or A. tumefaciens transformation steps might explain lack of infectivity for this construct.

The infectious full-length cDNA clone of Papaya leaf distortion mosaic virus (PLDMV) was recently constructed using In-Fusion cloning (Tuo et al. 2015). PLDMV belongs to the genus Potyvirus and its genome comprises 10,153 nucleotides excluding the poly (A) tail. Therefore, In-Fusion cloning has the potential of application to most filamentous RNA viruses.

Another major advantage of the full-length PCR of the $\sim 7.5 \mathrm{~kb}$ ACLSV genomic cDNA is its independence of the highly variable genome of ACLSV isolates published in the literature. The conserved terminal end sequences allow design and use of primers which can be applied to a wide range of isolates if not all ACLSV strains. This approach can be applied to other viruses that show high variability but with conserved terminal sequences (Yoon et al. 2014; Youssef et al. 2011b).

It is not unexpected that two variants of ACLSV were obtained from source 38/85. Single-strand conformation polymorphism analysis of the 3'-terminal 1.8-kb genomic cDNAs of 15 ACLSV isolates

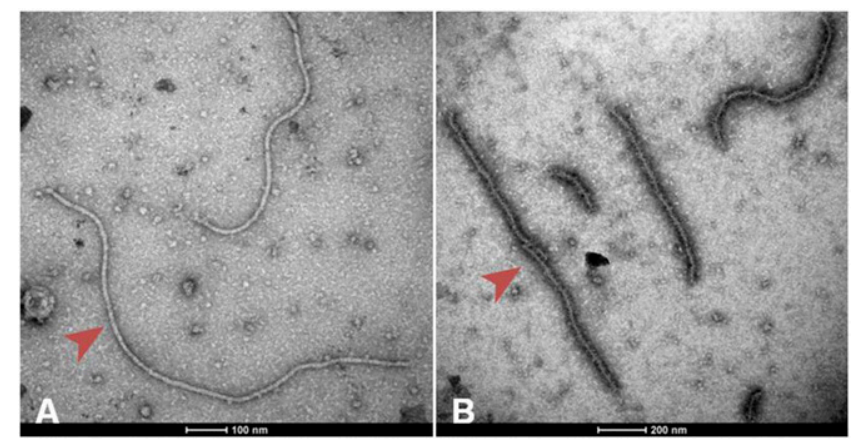

Fig. 3. ACLSV particles detected in a symptomatic N. occidentalis 37B infected with pIF3-15. The viral particles were indicated by red arrows. $\mathbf{A}$, viral particles observed under transmission electron microscope; B, viral particles decorated with antiserum of ACLSV-AS1236. Photo: K. Richert-Pöggeler, JKI, Institute for Epidemiology and Pathogen Diagnostics. 
revealed that at least two to four sequence variants were found in declining apple trees, while in nondeclining trees, a major type sequence was dominant (Nakahara et al. 2011).

The agroinoculation experiments of apple seedlings with a newly developed method were successful and highly efficient. In the vacuum infiltration treatment 3 , the survival rate of treated apple seedlings was above $70 \%$ and the PCR positive rate was above $78 \%$ (Fig. 4C). Although agroinoculated full-length viral cDNA clones could cause false positives in PCR detection, due to systemic spread of the bacterium in host species (Cubero et al. 2006), infections of ACLSV in woody plants were confirmed by IEM in addition to PCR detection. The vacuum infiltration parameters may influence the survival rates of infiltrated seedlings. With the vacuum parameters of treatment 1 , survival rates of $21 \%$ and $51 \%$ were observed for wounded and unwounded seedlings, respectively, while the much lower vacuum used in treatment 3 resulted in survival rates above $70 \%$. These results indicate that the high air pressure of $500 \mathrm{hPa}$ may be more beneficial to the survival of apple seedlings.

The wounding of cotyledons resulted in higher infection rates with the virus, but this was only done in treatment 1 . With wounding, the PCR positive rate of $80 \%$ for wounded seedlings was significantly higher than the $11 \%$ for unwounded seedlings. This result indicates that wounding of cotyledons considerably increased the efficiency of agroinoculation of the infectious full-length cDNA clones of ACLSV to woody plants. It has been reported that physical wounding of plants could significantly influence transformation efficiency (Norelli et al. 1996; Rashid et al. 1996). Crushing apple leaves using nontraumatic forceps before inoculation resulted in a 10-fold increase in the amount of transformation compared with the unwounded control (Norelli et al. 1996).

The cold pretreatment of apple seedlings might also influence the rates of infectivity. It is known that exposure of plants to low temperatures before inoculation may increase their susceptibility to disease. Cold pretreatment of seeds of bean, pea, maize, or cucumber, in the early stages of germination prior to being exposed to infection by Rhizoctonia solani Kühn, increased their susceptibility (Schulz and Bateman 1969). This cold treatment apparently reduced the vigor of the plants, and thus they were more sensitive to infection (Colhoun 1973). In another report using ACLSV inoculation, apple seedlings germinated in darkness at $4^{\circ} \mathrm{C}$ were inoculated by particle bombardment of total RNAs extracted from ACLSV-infected $C$. quinoa. After the biolistic inoculation, the seedlings were again placed in the dark at $4^{\circ} \mathrm{C}$ for 1 to 2 days. An efficiency of $86 \%$ (6/7) was observed (Yamagishi et al. 2010). In our work, the seedlings were always kept
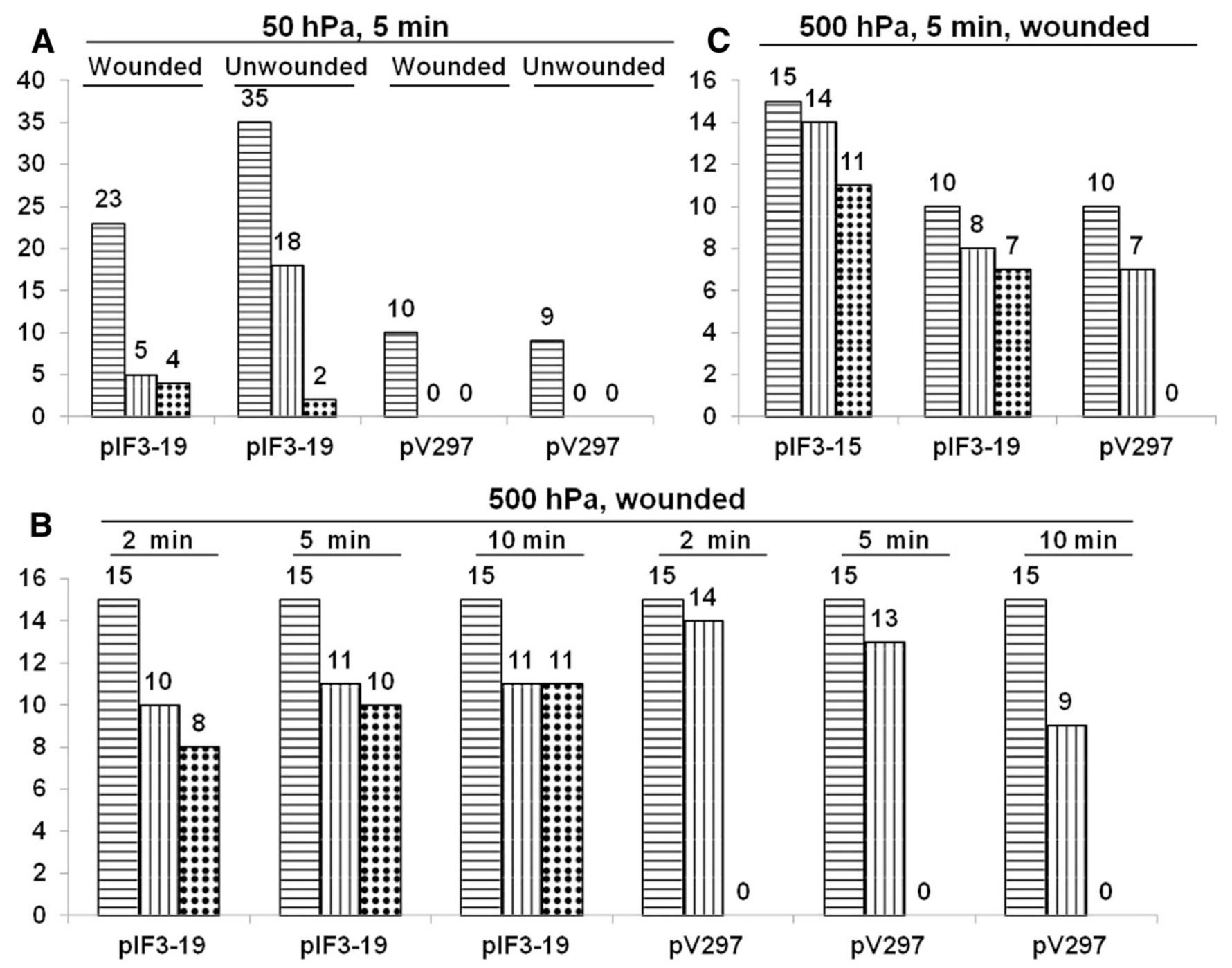

\footnotetext{
Number of infiltrated seedlings

Number of survived seedlings :: Number of PCR-positive seedlings
}

Fig. 4. Histograms showing the number of apple seedlings agroinoculated by vacuum infiltration, the number of seedlings that survived, and how many were PCR positive for ACLSV. The inocula contained infectious full-length cDNA clones of plF3-15 and plF3-19, respectively. The Agrobacterium containing pV297 was used as negative control. Wounded and unwounded apple seedlings were infiltrated. The vacuum parameters were: A, $50 \mathrm{hPa}$ for $5 \mathrm{~min} ; \mathrm{B}, 500 \mathrm{hPa}$ for 2, 5, and $10 \mathrm{~min}$, respectively; and C, $500 \mathrm{hPa}$ for 5 min. 
in a refrigerator at $4^{\circ} \mathrm{C}$ and similar infection rates were observed (78\%) (Fig. 4).

The newly developed protocol of agroinoculation of infectious full-length ACLSV cDNA clones described here should be applicable to other woody hosts. ACLSV has a wide range of woody hosts such as apple, pear, quince, peach, plum, almond, apricot, cherry, and hawthorns (Myrta et al. 2011; Yaegashi et al. 2011). It is reported that GF305 peach seedlings were infected with ACLSV P-205 by agroinfiltration (Youssef et al. 2011a), but at a low efficiency.

In summary, we constructed full-length cDNA clones of ACLSV isolate 38/85 using In-Fusion cloning. Two infectious cDNA clones of pIF3-15 and pIF3-19 were obtained. These two very distant virus strains were agroinoculated to apple seedlings by a newly developed vacuum infiltration method. The In-Fusion method can be recommended for construction of cDNA clones from full-length PCR fragments for other RNA viruses that possess conserved terminal ends.

\section{Acknowledgment}

We thank K. Richert-Pöggeler, Institute for Epidemiology and Pathogen Diagnostics, JKI, for her excellent support in Immnunoelectron microscopy. Lei Zhang acknowledges the financial support of the China Scholarship Council (CSC) for PhD Scholarship No. 201306300049.

\section{Literature Cited}

Ahlquist, P., French, R., Janda, M., and Loesch-Fries, L. S. 1984. Multicomponent RNA plant virus infection derived from cloned viral cDNA. Proc. Natl. Acad. Sci. USA 81:7066-7070.

Boscia, D., Savino, V., Minafra, A., Namba, S., Elicio, V., Castellano, M., Gonsalves, D., and Martelli, G. 1993. Properties of a filamentous virus isolated from grapevines affected by corky bark. Arch. Virol. 130:109-120.

Boyer, J.-C., and Haenni, A.-L. 1994. Infectious transcripts and cDNA clones of RNA viruses. Virology 198:415-426.

Chen, S., Zhou, Y., Ye, T., Hao, L., Guo, L., Fan, Z., Li, S., and Zhou, T. 2014. Genetic variation analysis of Apple chlorotic leaf spot virus coat protein reveals a new phylogenetic type and two recombinants in China. Arch. Virol. 159:1431-1438.

Colhoun, J. 1973. Effects of environmental factors on plant disease. Annu. Rev. Phytopathol. 11:343-364.

Conti, M., Milne, R., Luisoni, E., and Boccardo, G. 1980. A closterovirus from a stem-pitting-diseased grapevine. Phytopathology 70:394-399.

Cropley, R., Wolfswinkel, L. D., and Posnette, A. F. 1963. The identification of some viruses infecting apple, pear, and quince. Phytopathol. Mediterr. 2:132-136.

Cubero, J., Lastra, B., Salcedo, C., Piquer, J., and López, M. 2006. Systemic movement of Agrobacterium tumefaciens in several plant species. J. Appl. Microbiol. 101:412-421.

Dawson, W. O., Beck, D. L., Knorr, D. A., and Grantham, G. L. 1986. cDNA cloning of the complete genome of tobacco mosaic virus and production of infectious transcripts. Proc. Natl. Acad. Sci. USA 83:1832-1836.

Desbiez, C., Chandeysson, C., Lecoq, H., and Moury, B. 2012. A simple, rapid and efficient way to obtain infectious clones of potyviruses. J. Virol. Methods 183: 94-97.

Desvignes, J., and Boyé, R. 1988. Different diseases caused by the chlorotic leaf spot virus on the fruit trees. XIV Int. Sym. on Fruit Tree Virus Dis. Acta Hortic. 235:31-38.

Domier, L. L., Franklin, K. M., Hunt, A. G., Rhoads, R. E., and Shaw, J. G. 1989. Infectious in vitro transcripts from cloned cDNA of a potyvirus, tobacco vein mottling virus. Proc. Natl. Acad. Sci. USA 86:3509-3513.

Edwards, M. C., Weiland, J. J., Todd, J., and Stewart, L. R. 2015. Infectious Maize rayado fino virus from Cloned cDNA. Phytopathology 105:833-839.

Garnsey, S., Gonsalves, D., and Purcifull, D. 1977. Mechanical transmission of citrus tristeza virus. Phytopathology 67:965-968.

Hans, F., Fuchs, M., and Pinck, L. 1992. Replication of grapevine fanleaf virus satellite RNA transcripts in Chenopodium quinoa protoplasts. J. Gen. Virol. 73:2517-2523.

Hemenway, C., Weiss, J., O'Connell, K., and Tumer, N. E. 1990. Characterization of infectious transcripts from a potato virus X cDNA clone. Virology 175:365-371.

Ito, T., Koganezawa, H., and Yoshida, K. 1992. Back-transmission of apple russet ring A virus, an isometric virus isolated from an apple tree with fruit russet ring and leaf pucker symptoms, to apple seedlings. Ann. Phytopathol. Soc. Japan 58:617.

Janda, M., French, R., and Ahlquist, P. 1987. High efficiency T7 polymerase synthesis of infectious rna from cloned brome mosaic virus cdna and effects of $5^{\prime}$ extensions on transcript infectivity. Virology 158:259-262.

Jelkmann, W., and Kunze, L. 1994. Plum pseudopox in German prune after infection with an isolate of Apple chlorotic leafspot virus causing plum line pattern. XVI Int. Symp. on Fruit Tree Virus Dis. Acta Hortic. 386:122-125.

Jelkmann, W., Martin, R., Lesemann, D.-E., Vetten, H. J., and Skelton, F. 1990. A new potexvirus associated with strawberry mild yellow edge disease. J. Gen. Virol. 71:1251-1258

Lebas, B., Elliott, D., VandenBrink, R., Ochoa-Corona, F., Tang, J., and Alexander, B. 2003. Apple chlorotic leaf spot virus infection induces Plum
Pox virus-like symptoms on plum in New Zealand. XIX Int. Sym. on Virus and Virus-like Dis. of Temperate Fruit Crops-Fruit Tree Dis. Acta Hortic. 657:121-125.

Li, C., Sasaki, N., Isogai, M., and Yoshikawa, N. 2004. Stable expression of foreign proteins in herbaceous and apple plants using Apple latent spherical virus RNA2 vectors. Arch. Virol. 149:1541-1558.

MacKenzie, D. J., McLean, M. A., Mukerji, S., and Green, M. 1997. Improved RNA extraction from woody plants for the detection of viral pathogens by reverse transcription-polymerase chain reaction. Plant Dis. 81:222-226.

Meng, B., Venkataraman, S., Li, C., Wang, W., Dayan-Glick, C., and Mawassi, M. 2013. Construction and biological activities of the first infectious cDNA clones of the genus Foveavirus. Virology 435:453-462.

Menzel, W., Jelkmann, W., and Maiss, E. 2002. Detection of four apple viruses by multiplex RT-PCR assays with coamplification of plant mRNA as internal control. J. Virol. Methods 99:81-92.

Muruganantham, M., Moskovitz, Y., Haviv, S., Horesh, T., Fenigstein, A., du Preez, J., Stephan, D., Burger, J. T., and Mawassi, M. 2009. Grapevine virus A-mediated gene silencing in Nicotiana benthamiana and Vitis vinifera. J. Virol. Methods 155:167-174.

Myrta, A., Matic, S., Malinowski, T., Pasquini, G., and Candresse, T. 2011. Apple chlorotic leaf spot in stone fruits. Pages 85-90 in: Virus and Virus-like Diseases of Pome and Stone Fruits. A. Hadidi, M. Barba, T. Candresse, and W. Jelkmann, eds. American Phytopathological Society, St. Paul, MN.

Nagyová, A., and Subr, Z. 2007. Infectious full-length clones of plant viruses and their use for construction of viral vectors. Acta Virol. 51:223-237.

Nakahara, K. S., Yoshida, K., Suzaki, K., Yoshikawa, N., and Ito, T. 2011. Sensitive PCR-based detection of Apple chlorotic leaf spot virus heterogeneous in apple trees. Jpn. Agric. Res. Q. JARQ 45:411-421.

Németh, M. V. 1986. Virus, mycoplasma, and rickettsia diseases of fruit trees. Martinus Nijhoff, Dordrecht, Netherlands.

Norelli, J., Mills, J., and Aldwinckle, H. 1996. Leaf wounding increases efficiency of Agrobacterium-mediated transformation of apple. HortScience 31:1026-1027.

Rashid, H., Yokoi, S., Toriyama, K., and Hinata, K. 1996. Transgenic plant production mediated by Agrobacterium in indica rice. Plant Cell Rep. 15:727-730.

Rott, M., and Jelkmann, W. 2001. Characterization and detection of several filamentous viruses of cherry: adaptation of an alternative cloning method (DOP-PCR), and modification of an RNA extraction protocol. Eur. J. Plant Pathol. 107:411-420.

Satoh, H., Yoshikawa, N., and Takahashi, T. 1999. Construction and biolistic inoculation of an infectious cDNA clone of Apple chlorotic leaf spot trichovirus. Ann. Phytopathol. Soc. Jpn. 65:301-304.

Schulz, F., and Bateman, D. 1969. Temperature responses of seeds during early phases of germination and its relation to injury by Rhizoctonia solani. Phytopathology 59:352-355.

Stevenson, J., Krycer, J. R., Phan, L., and Brown, A. J. 2013. A practical comparison of ligation-independent cloning techniques. PLoS One 8:e83888.

Sutton, T. B., Aldwinckle, H. S., Agnello, A. M., and Walgenbach, J. F. 2014 Compendium of Apple and Pear Diseases And Pests. American Phytopathological Society, St. Paul, MN.

Tuo, D., Shen, W., Yan, P., Li, X., and Zhou, P. 2015. Rapid construction of stable infectious full-length cDNA clone of Papaya leaf distortion mosaic virus using in-fusion cloning. Viruses 7:6241-6250.

Vervliet, G., Holsters, M., Teuchy, H., Van Montagu, M., and Schell, J. 1975. Characterization of different plaque-forming and defective temperate phages in Agrobacterium strains. J. Gen. Virol. 26:33-48.

Vives, M. C., Martin, S., Ambros, S., Renovell, A., Navarro, L., Pina, J. A., Moreno, P. and Guerri, J. 2008. Development of a full-genome cDNA clone of Citrus leafblotch virus and infection of citrus plants. Mol. Plant Pathol. 9:787-797.

Xiang, C., Han, P., Lutziger, I., Wang, K., and Oliver, D. J. 1999. A mini binary vector series for plant transformation. Plant Mol. Biol. 40:711-717.

Yaegashi, H., Isogai, M., Tajima, H., Sano, T., and Yoshikawa, N. 2007. Combinations of two amino acids (Ala40 and Phe75 or Ser40 and Tyr75) in the coat protein of Apple chlorotic leaf spot virus are crucial for infectivity. J. Gen. Virol. 88:2611-2618.

Yaegashi, H., Yoshikawa, N., and Candresse, T. 2011. Apple chlorotic leaf spot virus in Pome Fruits. Pages 17-21 in: Virus and virus-like diseases of pome and stone Fruits. A. Hadidi, M. Barba, T. Candresse, and W. Jelkmann, eds. American Phytopathological Society, St. Paul, MN.

Yamagishi, N., Sasaki, S., and Yoshikawa, N. 2010. Highly efficient inoculation method of apple viruses to apple seedlings. Julius-Kühn-Archiv. 427:226-229.

Yanase, H. 1974. Studies on apple latent viruses in Japan: The association of apple top-working disease with apple latent viruses. Bull. Fruit Tree Res. Stn. C1:47-109.

Yoon, J. Y., Joa, J. H., Choi, K. S., Do, K. S., Lim, H. C., and Chung, B. 2014 Genetic diversity of a natural population of Apple stem pitting virus isolated from apple in Korea. Plant Pathol. J. 30:195-199.

Yoshikawa, N. 2001. Apple chlorotic leaf spot virus. CMI/AAB Description of Plant Viruses 386.

Yoshikawa, N., and Takahashi, T. 1988. Properties of RNAs and proteins of apple stem grooving and apple chlorotic leaf spot viruses. J. Gen. Virol. 69:241-245.

Youssef, F., Marais, A., Faure, C., Barone, M., Gentit, P., and Candresse, T. 2011b. Characterization of Prunus-infecting Apricot latent virus-like Foveaviruses: Evolutionary and taxonomic implications. Virus Res. 155:440-445.

Youssef, F., Marais, A., Faure, C., Gentit, P., and Candresse, T. 2011a. Strategies to facilitate the development of uncloned or cloned infectious full-length viral cDNAs: Apple chlorotic leaf spot virus as a case study. Virol. J. 8:488. 